\title{
LEGISLATION OF THE SOCIAL AND LEGAL STATUS OF SELF-EMPLOYED PERSONS IN UKRAINE
}

Ganna I. Bagirova

Postgraduate student of the Department of Civil Law and Procedure of National Aviation University

1 Liubomyr Huzar Ave., Kyiv, Ukraine, 03058

https://orcid.org/0000-0001-8224-0371

gannazdorenko@gmail.com

\begin{abstract}
Nowadays in countries with developed industry, there is a marked shift from formal to informal employment. In this context, the impact of self-employment on the development of the state should be one of the topical issues in the debate on employment policy.

Due to the development of the platform economy, self-employment is developing as the main or additional source of income. The development of Ukraine as a socially oriented state governed by the rule of law is determined by the level of development of all state spheres, including self-employment of the population of state institutions, including the institution of personal income taxation.

As of today, in countries with developed industry, there is a marked shift from formal to informal employment. In this context, the impact of self-employment on the development of the state should be one of the topical issues in the debate on employment policy. Due to the development of the platform economy, self-employment is developing as the main or additional source of income. The development of Ukraine as a socially oriented state governed by the rule of law is determined by the level of development of all state spheres, including self-employment of the population of state institutions, including the institution of personal income taxation.

It was emphasized that the above-mentioned provisions of international legal acts became the basis for consolidation of the principles of labor freedom and the prohibition of forced labor in the Constitution of Ukraine. In turn, these constitutional principles are the normative and legal basis for the consolidation of the principle of freedom of labor agreement within the framework of labor law.

It has been established that the establishment in the national legislation of the principle of freedom of the labor contract should enable an employed person and an employer who exercises the right to recruit staff to determine the working conditions that are most appropriate for them. The terms of the employment contract should not be burdensome for their parties and disturb.
\end{abstract}


In such situations, the legislator prefers social rather than economic rights, since social law is more closely connected with the natural right of a person to life and freedom and security.

Keywords: self-employed person; status of self-employed persons; a person pursuing an independent professional activity; a person who is self-employed.

\section{INTRODUCTION}

The main purpose this article is research and analysis of theoretical and practical problems, development of legislation on the social and legal status of self-employed persons in Ukraine.

In modern conditions, the level of scientific development of theoretical and practical problems of self-employment is at an early stage. It should be noted that in the conditions of market transformations, self-employment for a certain part of the population is a way to survive in difficult life situations.

Self-employment as a type of economic behavior can be described, on the one hand, as a strategy to ensure living conditions in a changing life situation and solve the problem of unemployment, and on the other - as the first step in the implementation of entrepreneurial behavior.

The transition of self-employment to entrepreneurial activity is a social indicator of maturity of the subject of individual labor activity.

Self-employment is a manifestation of further self-organization of individuals and is characterized as a strategy to solve the problem of unemployment and ensure proper living conditions. Determined by autonomy and freedom of action, self-employment ideally allows a person to receive income, adequate quantity and quality of labor and investment.

At the legislative level, the term "self-employed person" has the following definition.

A self-employed person is a taxpayer who is an individual entrepreneur or carries out an independent professional activity, provided that such a person is not an employee within such entrepreneurial or independent professional activity.

Self-employment differs from traditional employment with regular remuneration by its inherent autonomy and individual orientation, which contributes to the gradual formation of a fundamentally new stratum of the economically active population, which has abandoned paternalistic expectations. This is the social value of self-employment.

The most common type of self-employment is entrepreneurial activity, which includes a system of actions and deeds related to starting your own business, business activity, risk. The market environment expands the freedom to choose the scope of labor, the possibility of applying labor, which, combined with the responsibility of economic entities for the results of production, promotes the development of effective forms of self-employment, including small business.

Interest in self-employment is due to the following circumstances:

- lower production, which resulted in rising unemployment and narrowing employment opportunities; 
- low level of wages at state, private joint-stock and collective enterprises, frustration of the population in the use of labor at enterprises of various forms of ownership;

- the establishment of market consciousness among the majority of citizens;

- the need to change the principles of social policy of the state, focus on intensifying the behavior of all working groups, overcoming the passive expectation of state assistance.

Acquiring the status of self-employed persons is a rather problematic issue in the legal regulation of self-employed workers, as there are still gaps in the legislation in this regard.

The lack of the status of a self-employed person, the procedure for its acquisition, loss, etc. has the consequence that the person must either acquire the legal status of a natural person - entrepreneur, or engage in independent professional activity.

It should be noted that a person has the right to conduct independent professional activity only in the case of state registration of such activity, in accordance with the requirements of current legislation of Ukraine.

Due to the long period of economic development and the process of improving the current legislation, the category of "self-employed person" has not received its proper development and legal consolidation. Currently, there is no holistic view of the concept, and there is a lack of an integrated approach to defining its classification features, there are insufficient theoretical and legal developments on the formation of the legal status of a self-employed person as a subject of social security law.

Self-employment is a complex socio-economic phenomenon. On the one hand, this is evidence of the lack of other ways and opportunities for formal employment. Selfemployment in some way stimulates the further development of the informal sector of the economy. On the other hand, the bearers of social and labor potential independently provide themselves with socially useful types of work, contribute to the creation of a competitive environment, create a natural social support for the social order and form a new social class of entrepreneurs.

According to Azmuk, self-employed people have significant incentives for self-expression and self-affirmation, which allows them to receive income much higher than the average salary in the industry (Azmuk, 2012).

The very definition of "self-employment" is still debatable. Sobol notes that self-employment is a relatively new phenomenon in the domestic economy, which began to develop in the transition period to market conditions. In the scientific literature and statistical practice of different countries, the terms "self-employment" and "a person pursuing an independent professional activity" are used to denote employment without legal registration of employment contracts.

According to the definition of the International Classification of Employment Status (ICSE93), self-employment means working in one's own enterprise, when the remuneration directly depends on the income received from the production of products and services (Sobol, 2008).

The opinion of Barsuchenko, who argues that self-employment, is a specific form of economic activity. The essence of which is that the citizen himself finds a source of income that will ensure his proper existence as a result of his economic activity (Barsuchenko, 2013). 
However, there is currently no single approach to understanding this phenomenon, despite the large number of scientific papers on the legal status of the self-employed person.

Rabinovych defines the legal status of a person as a set of his subjective legal rights and legal obligations (Rabinovych, 2007).

Skakun, in addition to the rights, freedoms and responsibilities of the person, the structure of the legal status of the person includes responsibility, according to which the individual as a subject of law coordinates its behavior in society (Skakun, 2001).

Self-employment as a social phenomenon is recognized as a powerful means of economic development and easing of social tensions. This approach is implemented in Article 8 of the Law of Ukraine "On the Principles of Domestic and Foreign Policy", according to which the main principles of domestic policy in the social sphere are overcoming poverty and reducing social stratification, in particular by promoting self-employment.

In the current Labor Code of Ukraine, there is virtually no legal regulation of the activities of self-employed persons as participants in labor relations.

There is currently an inexhaustible list of self-employed persons in Ukraine. These include lawyers, private notaries, scholars, writers, artists, painters, private teachers, doctors, arbitrators, auditors, accountants and others.

A self-employed person as an employer, who uses the hired labor of individuals on the basis of concluded employment agreements (contracts), bears obligations to pay them wages, as well as accrual, withholding and payment of personal income tax to the budget, accruals to the payroll, other responsibilities provided by law.

In addition, a self-employed person who accrues and pays income for the performance of work and / or provision of services in accordance with a civil law contract is equated to the employer if it is established that the relationship under such a contract is in fact an employment contract. Such reformatting of relations from civil to labor is supported by theorists of labor law, pointing out that "the science of labor law has long formed the idea that labor relations arising from civil contracts or services should be governed by labor law.

Moreover, that fact should be considered as a differentiation of relations that are the subject of labor law.

A self-employed person who performs work on behalf of another person and is a party to a civil contract is not considered to be subject to labor regulations. Only in some cases can a self-employed person be equated with an employee with the corresponding taxation of income received by him as a salary. That is, if the relationship under the relevant civil contract is established by the employment relationship and the parties to the contract can be equated to an employee or robot.

In order to legislate the support and development of self-employment, scientists have developed a list of necessary procedures, namely:

- to develop and adopt a law "On individual labor activity", which would regulate the activities of public authorities and local governments in relation to the development of self-employment;

- to protect the rights of self-employed persons, it is necessary to promote the creation of an appropriate "trade union" at the state level, in order to protect their interests, as well as to promote their social development in accordance with accepted national standards; 
- consider the issue of state social insurance of the self-employed population;

- Special attention and legislative regulation today requires employment in a personal subsidiary family farm, employment in the care of the disabled and the elderly.

To improve the legal framework for the development of self-employment it is necessary:

- introduction of self-employment in the legal circle of the state: the development of the legal concept of self-employment, a clear definition of categories of people belonging to this segment of the labor market;

- legislative regulation of issues of self-employment, registration, accounting, social insurance, pensions, simplified taxation and other protection;

- supplementing labor legislation with regulations in accordance with the conditions of a market economy and stimulating economic activity of the population;

- development of legal terms for homework and individual, family contracts, in accordance with the recommendations of the Ministry of Labor Protection

\section{MATERIALS AND METHODS}

Many prominent domestic scientists have paid attention to the question of the characteristics of self-employed persons.

In this article are used such methods as documentary analysis and synthesis, comparative analysis, objective truth, cognitive-analytical, etc.

Quite common in science is the approach according to which the self-employed persons are those persons who independently organize their work for their own account, own the means of production, are responsible for the production products and independently sell it. This view is shared, in particular, Roffe, Zbyshko, Inshin, Nikiforova, Libanova and others.

The definition proposed by the authors provides determination of the appropriate category through the characteristics of the main features self-employed activities.

This approach is more justified than the concepts discussed above, however, in our opinion, it needs specification.

Freedom of work comes from the natural state of a person born free and must remain free throughout his life. There is no doubt that labor freedom should be considered as one of the most important and most valuable legal principles that permeates not only the legislation of individual countries but is a fundamental legal principle recognized by all countries of the world and international communities. The study of the principles of legal regulation and scientific material on labor freedom convinces that the principle of freedom of labor is directly or indirectly manifested in all norms of labor law. In other words, the principle of freedom of labor is inextricably linked with the principle of freedom of contract. Since labor law was separated from the time of civil law, freedom of contract, first of all, is the principle of civil law, although the very idea of freedom is the basis for all law and legal doctrines

The current state of youth employment in Ukraine and youth self-employment as one of ways of overcoming unemployment among this category of population is analyzed. The regulatory framework, which determines the place of youth self-employment in public youth policy and in the employment system of country population and regulates various aspects of public support of this direction, is characterized. 
The mechanism of public support of youth self-employment in Ukraine shall be worked out within the implementation of public youth policy, the system of population employment, general economic policy - regarding the regulation of business activity, innovation policy in the context of support of high-tech projects and start-ups.

The position on the necessity of forming a policy of development of self-employed of the population, which is significant in financial and legal aspects is argued. It has been proved that the development of self-employed will increase revenues to the budgets of different levels. It is substantiated that a self-employed persons' work is more effective than a work of employee, because of a great own motivation in getting the best results of own activity.

It is proposed to introduce differentiated approach for defining the legal status of individual and collective subjects, which are related although different by their nature.

A person's legal status is based on natural human rights, while the legal status of collective entities is not similar and determined by the personality of this status: legal entities (governmental and non-governmental bodies, enterprises, organizations, and institutions), state and its structure units, people, social communities etc.

The range of rights from one party has an influence on other party. For example, a valueadded tax is different for operations between usual taxpayers and between those who have special tax regime with a flat tax. The status of fiscal resident in taxation or opportunity to determine status of tax agent, etc. has a great influence.

The obligation of accounting of private notaries is the same as reporting obligations, because summary accounting imply the creation and introducing a tax declaration. They provide the declaration accordingly results for reporting year in terms for income tax payers (to 1st May in the first year following the reporting year).

However, person who is responsible for assessment, obtaining and payment (recalculation) of this tax is a taxpayer - physical person, but not notary.

Accordingly, the taxpayer is liable for tax evasion. The notary does not have the obligation to audit the accuracy of the value of property.

\section{RESULTS AND DISCUSSION}

It was found that self-employment is a complex socio-economic phenomenon, which is evidence of the lack of other ways and opportunities for formal employment.

It was found that the interpretation of the concept of "self-employment" still remains controversial among scholars.

In the doctrine, there are different approaches to understanding the category of selfemployed persons. For example, Kupalova believes that the category of self-employed persons are non-employed, namely: employers (employee's owners) engaged in individual (independent) employment, free working family members.

It is clear that the key feature of the self-employed person is the realization of the right to work without entering into a relationship of "power and subordination "with the employer, i.e. without concluding an employment contract.

However, in our opinion, this approach does not fully reveal the essence of the studied category and needs clarification. 
Kilnytska, who believes that self-employed persons are non-employed persons, i.e. people who have their own business, proposed a similar definition.

The above definition is general character and it does not contain any characteristic, distinctive features, etc., which are inherent in self-employment as a separate type of employment.

In such circumstances, such a definition, in our opinion, more reflects the domestic understanding of the relevant category of workers, but for the purposes of scientific theoretical research, it is not acceptable.

In addition, such a sign as independent sale of self-employed persons of its products, too, can not be defined as general. For example, a person may engage in particular type activities, but also to provide services (goods or works) to another entity, which deals with their implementation to end users.

Therefore, this approach has enough positive features, although it is present and significant inaccuracies that need to be corrected.

Scientific novelty of the obtained results. The work is one of the first in Ukrainian legal literature research of the legal status of the self-employed persons as payers of taxes and fees. Scientific novelty is reflected in the following provisions:

first:

- a specific form of legal representation in representing the interests of legal entities, when in relations with regulatory authorities their legal representatives are managers, deputies, accountants and other persons authorized to represent the organization in accordance with its constituent documents, and the source of authority of the representative are statutory documents, which enshrines the ability to represent the interests of a legal entity, which reflects the close relationship between tax and economic regulation, when in fact the economic and legal mechanisms are used in determining the tax status of the taxpayer;

- the duality of the tax and legal status of private notaries as participants in tax relations is determined, when, on the one hand, they are self-employed and have to fulfill their own tax liability, and on the other hand - contribute to the proper implementation of tax liability by other individuals. Real estate transactions (only in the latter case they can be classified as tax-contributing persons);

- it is proposed to improve the normative consolidation of the procedure for deprivation of the status of certain categories of self-employed persons by differentiating the grounds for such deprivation on the basis of tort, which determines the existence of fundamentally different procedures and differentiation of consequences.

improved:

- description of the legal status of the notary in the tax relations, which has a twofold nature: based on the content of specific tax relations in which the notary acts as a participant, he may play the role of a taxpayer or a subject of information exchange (a person who facilitates the payment of taxes and fees);

- the grounds for tax liability of certain categories of taxpayers, when the legal fact that determines the tax liability may not be the presence of the object of taxation, and obtaining a special tax status: single tax payers 1 and 2 groups must pay it in a fixed 
amount and receive income as one of the types of object of taxation in this case does not matter for the tax liability, which is important for detailing the legal status of selfemployed persons, because their circle includes individuals persons - entrepreneurs;

- a mechanism of compulsory insurance of notaries, which will promote the development of this category of self-employed persons and in the long run will lead to an increase in tax revenues to the state from their activities.

\section{CONCLUSIONS}

Thus, the main shortcomings in the legal regulation of self-employed persons are the obsolescence of legislation on employment. It should be concluded that the essence of self-employment as a type of economic behavior is that a person finds a source of income, provides adequate to his needs level and living conditions as a result of economic activity, which is regulated by social and economic norms.

There is no clear legal definition of the concept of "self-employed persons", its identity with the concept of "self-employed persons", the lack of an exhaustive legislative list of entities that belong to this category. In this regard, it is quite urgent to define a unified approach to the legislative consolidation of the concept of self-employed persons, a clear definition of the circle of these persons, the regulation of relevant legislation.

Summarizing the above, it should be noted that self-employment is a phenomenon that has not been thoroughly studied, not fully studied, not created a clear core on which to build the structure of this concept. Self-employment is a constant dynamic process that depends on the economic situation in the country, and therefore this concept needs constant reform in approaches to understanding its essence.

It is established that a special tax regime for the self-employed persons determines not only the specificity of the consolidation of their rights and responsibilities and forms their implementation, but also determines the grounds for calculating the amount of tax payment.

To the main elements of the tax mechanism along with the payer, include object of taxation, based on the definition of which, you can find out the base taxation, and already on this basis to determine the amount of tax payment.

Taxable income of persons in the conduct of a certain type of independent professional activity is the total net income that is determined as the difference between income and documented expenses, necessary for carrying out a certain type of such activity. Taxation other categories of individuals do not include costs.

The duality of the consequences of the introduction in our state has also been determined compulsory insurance of certain categories of self-employed persons.

On the other hand, such requirements reduce the tax base accordingly reduce budget revenues. On the other hand, by a certain centralization and public legalization of such activities are strengthened guarantees for consumers of notary services.

It is expedient to divide self-employed persons on the basis of accounting (registration) into two groups. The first includes people who must register as self-employed, the second group - persons who conduct independent professional activities and are not registered separately by self-employed persons. 
To the last, belong to persons involved in scientific, literary, artistic, artistic, educational or teaching activities.

\section{REFERENCES}

Azmuk, N.A. (2012). Transformation of the structure of occupation of the population of Ukraine: prospects for the development of nasty forms of organization of work. Formation of the market economy, 1, 35-43.

Barsuchenko, A.S. (2013). Self-determination on the market of practice: freelance, 16, 11-13.

Rabinovich, P. M. (2007). Foundations of the foreign theory of the law of that state: the head master. 9th type., In the winters, Kyiv; Lviv: Krai.

Skakun, O. F. (2001). Theory of power and law: handler / per. from growing up. Kharkiv: Consum.

Sobol, S.N. (2008). Content, principles of the kind of educational activity in the minds of the transformation of the forms of the state's gratitude to the industrial enterprises, Lviv, 3 (29), 45-59. 